\title{
UJI AKTIVITAS ANTIINFLAMASI EKSTRAK ETANOL BUNGA BUGENVIL (Bougainvillea spectabilis) TERHADAP TIKUS PUTIH GALUR WISTAR
}

\author{
Triska Gea Ambasalu, Mirhansyah Ardana, Muhammad Amir Masruhim \\ Laboratorium Penelitian dan Pengembangan FARMAKA TROPIS \\ Fakultas Farmasi Universitas Mulawarman, Samarinda, Kalimantan Timur \\ Email : geatriska@gmail.com
}

\begin{abstract}
ABSTRAK
Penelitian ini bertujuan untuk mengetahui efek antiinflamasi ekstrak bunga bugenvil terhadap edema buatan pada tikus Wistar dan mengetahui dosis ekstrak etanol bunga bugenvil yang paling efektif terhadap penurunan volume edema tikus jantan yang diinduksi karagenan $1 \%$. Subjek penelitian ini adalah 15 ekor tikus jantan galur Wistar yang dibagi menjadi 5 kelompok; kontrol negatif ( $\mathrm{NaCMC} \mathrm{0,5 \% ),} \mathrm{kontrol} \mathrm{positif} \mathrm{(Natrium}$ diklofenak $0,9 \mathrm{mg} / \mathrm{kgBB})$, kelompok perlakuan $(200 \mathrm{mg} / \mathrm{kgBB}, 250 \mathrm{mg} / \mathrm{kgBB}$, $300 \mathrm{mg} / \mathrm{kgBB}$ ), diberikan secara oral. Telapak kaki belakang kanan tikus disuntikkan secara subkutan karagenan $1 \%$ untuk memicu inflamasi. Pengukuran volume edema dilakukan dengan menggunakan pletismometer dalam selang waktu 30 menit selama 330 menit. Data selanjutnya dianalisis menggunakan ANAVA dua arah dan dilakukan uji lanjutan dengan menggunakan analisis Tukey. Hasil penelitian menunjukkan bahwa ekstrak etanol bunga bugenvil mampu menurunkan volume edema pada kaki tikus putih galur wistar yang diinduksi karagenan $1 \%$ dan dosis efektif ekstrak bunga bugenvil sebagai antiinflamasi adalah pada dosis $250 \mathrm{mg} / \mathrm{kgBB}$. Selanjutnya dilakukan uji potensi ekstrak bunga bugenvil dosis $250 \mathrm{mg} / \mathrm{kgBB}$ dengan kontrol positif menggunakan uji t dan terlihat bahwa terdapat perbedaan yang nyata pada pemberian ekstrak bunga bugenvil $250 \mathrm{mg} / \mathrm{kgBB}$ dengan kontrol positif.
\end{abstract}

Kata kunci :Bougainvillea spectabilis, Antiinflamasi, Tikus putih, Na-Diklofenak

\begin{abstract}
The purpose of this research is to know the anti anti-inflammatory effect of Bougainvillea flowers (Bougainvillea spectabilis) extract on artificial edema in Wistar rat and determine ethanol extract dose from Bougainvillea flowers that most effective for decrease the volume of foot edema male rats induced with $1 \%$ carrageenin. This research used 15 white male rats which divided into 5 groups; negative control group (NaCMC 0,5\%), positive control group (Natrium dickofenac 0,9 $\mathrm{mg} / \mathrm{kgBB}$ ), treatment group (ethanol extract of Bougainvillea flowers dose $200 \mathrm{mg} / \mathrm{kgBW}, 250 \mathrm{mg} / \mathrm{kgBW}$ and $300 \mathrm{mg} / \mathrm{kgBW}$ ) were administered per orraly. Rat's right sole of foot injected subcutaneously with $1 \%$ carrageenin. The volume measurement performed with 30 minutes interval 330 minutes using pletysmometer. Furthermore, the data were analyzed with 2 ways ANOVA and advance study with turkey analysis. The result show if ethanol extract of Bougainvillea flowers have an effect to decrease edeme volume from wistar rat foot which induced with $1 \%$ carrageenin and the effective dose from ethanol extract of Bougainvillea flowers as antiinflammatory is $250 \mathrm{mg} / \mathrm{kgBW}$ dose. Furthermore, advanced experiment was do to know anti inflammatory potention from $250 \mathrm{mg} / \mathrm{kgbb}$ dose of ethanol extract of
\end{abstract}


Bougainvillea flowers with postive control using $t$ test and the result show if there an obvious difference from $250 \mathrm{mg} / \mathrm{kgBW}$ dose of ethanol extract from Bougainvillea flowers with positive control.

Keywords: Bougainvillea spectabilis, Antiinflammatory, Wistar Rats, Na-Diklofenak

\section{PENDAHULUAN}

Indonesia merupakan negara yang memiliki berbagai macam tanaman, baik berupa tanaman obat maupun tanaman hias. Kebanyakan masyarakat memanfaatkan tanaman obat untuk mengobati berbagai macam penyakit. Salah satu penyakit yang sering terjadi di masyarakat umum adalah inflamasi. Masyarakat tidak mengetahui bahwa ada beberapa tanaman hias yang juga dapat mengobati penyakit inflamasi. Tanaman hias sama halnya dengan tanaman obat yang diharapkan memberikan efek yang maksimal dengan meminimalkan efek samping. Berdasarkan beberapa penelitian tanaman dengan kandungan metabolit sekunder memiliki potensi sebagai antiinflamasi. Salah satu tanaman hias yang berpotensi untuk mengobati radang adalah bugenvil.

Bugenvil secara umum merupakan tanaman hias yang ditanam hampir di seluruh daerah tropis maupun subtropis. Tanaman ini memiliki famili Nyctaginaceae dengan 14 spesies yang diperoleh dari proses persilangan bugenvil (Kobayashi, 2007) dengan kandungan berupa flavonoid, glycosides, alkaloid, phlobotannins, saponin, steroid, tannin dan terpenoid. Namun hanya terdapat 3 spesies yang bugenvil yang merupakan induk dari silangan tersebut yaitu Bougainvillea spectabilis, Bougainvillea glabra dan Bougainvillea peruviana (Rashid, 2013).

Bugenvil dengan spesies Bougainvillea glabra dan Bougainvillea peruviana dilaporkan telah memiliki aktivitas antiinflamasi. Adapun khasiat atau manfaat dari bugenvil berdasarkan penelitian diantaranya adalah daun Bougainvillea glabra dilaporkan memiliki aktivitas antiinflamasi, antimikroba ulcer, aktivitas antihiperglikemia dan antidiarrhoeal (Joshny, 2012). Bunga bougenvill glabra juga diteliti memiliki aktivitas sebagai antibakteri (Enciso, 2012). Kandungan dari bugenvil jenis ini adalah protein, steroid, glikosida, flavonoid, alkaloid, komponen fenolik dan tannin yang telah diuji secara kualitatif (Sahu, 2012).

Berdasarkan uraian diatas maka penulis ingin meneliti aktivitas antiinflamasi dari bunga Bugenvil dengan spesies Bougainvillea spectabilis dengan pendekatan berdasarkan kesamaan genus dari Bougainvillea serta kandungan metabolit sekunder berupa flavonoid yang juga dimiliki oleh Bougainvillea spectabilis (Rashid, 2013) dengan mengujikannya pada hewan coba yaitu tikus putih dengan mengkondisikannya dalam keadaan bengkak dengan induktor karagenan.

\section{METODE PENELITIAN}

\section{Bahan}

Bahan-bahan yang digunakan dalam penelitian ini antara lain bunga bugenvil, etanol $70 \%$, Natrium diklofenak, $\mathrm{NaCMC}, \mathrm{NaCl} 0,9 \%$, aquades, karagenan, tikus putih galur wistar.

\section{Peralatan}

Alat yang digunakan dalam penelitian ini antara lain: wadah maserasi, rotary evaporator, pletismometer, timbangan analitik, waterbath, oven, spoid, sonde oral, labu takar, gelas ukur, pipet volume, botol coklat, gelas kimia, mortir dan stamper, batang pengaduk, corong kaca. 


\section{Prosedur Penelitian}

\section{Pengumpulan Bahan Tumbuhan}

Bunga bugenvil (Bougainvillea spectabilis) dikumpulkan kemudian dibersihkan dari kotoran dengan air mengalir dan ditimbang beratnya, kemudian dikeringkan dengan cara diangin-anginkan didalam ruangan yang terlindung dari sinar matahari secara langsung hingga diperoleh bunga bugenvil kering.

\section{Pembuatan Ekstrak Etanol Bunga Bugenvil}

Pembuatan ekstrak etanol bunga bugenvil dilakukan dengan cara maserasi. Simplisia bunga bugenvil sebanyak $87 \mathrm{~g}$ dengan menggunakan timbangan analitik kemudian dimasukkan ke dalam toples kaca transparan yang tertutup rapat dan dimaserasi dengan pelarut etanol $70 \%$. Didiamkan selama 3x24 jam atau hingga warna pelarut menjadi pekat lalu ditampung maserat (hari pertama). Diulangi perlakuan yang sama hingga diperoleh pelarut berwarna bening yang menandakan senyawa telah terekstraksi sempurna. Maserat yang diperoleh kemudian dipekatkan dengan menggunakan rotary evaporator hingga diperoleh ekstrak kental. Sisa pelarut selanjutnya diuapkan di atas water bath hingga diperoleh ekstrak kering kemudian disimpan pada desikator.

\section{Perhitungan Rendamen}

Rendamen diperoleh dari membandingkan antara berat bobot ekstrak etanol kasar dengan bobot simplisia kering dikali $100 \%$.

\section{Pengujian Efek Antiinflamasi}

Sebelum pengujian, semua hewan uji dipelihara dalam kondisi yang sama.

Tikus putih diadaptasikan dengan lingkungan penelitian selama satu minggu dan sebelum pemberian perlakuan tikus dipuasakan selama 18 jam dengan tetap diberikani minum. Tikus dikelompokkan menjadi 5 kelompok yaitu kelompok kontrol positif, kontrol negatif dan kelompok bahan uji dengan 3 varian dosis $(200 \mathrm{mg} / \mathrm{kgBB}, 250 \mathrm{mg} / \mathrm{kgBB}$ dan 300 $\mathrm{mg} / \mathrm{kgBB}$ ).

Saat pengujian, masing-masing hewan uji ditimbang dan diberi tanda pada kaki kirinya. Masing-masing tikus pada tiap kelompok diberikan uji peroral sesuai dengan pembagian kelompok yaitu kelompok I diberikan suspense Na-diklofenak, kelompok II diberi NaCMC 0,5\% sebagai kontrol negatif, kelompok III, IV dan V diberi suspensi ekstrak bunga bugenvil dengan dosis masing-masing $200 \mathrm{mg} / \mathrm{kgBB}, 250 \mathrm{mg} / \mathrm{kgBB}$ dan 300 $\mathrm{mg} / \mathrm{kgBB}$. Pada 30 menit setelah pemberian oral dilakukan pengukuran volume udem pada kaki tikus putih sebelum diinduksi karagenan yang dinyatakan sebagai $\mathrm{V}_{0}$. Setelah dilakukan pengukuran pada masing-masing telapak kaki tikus putih kemudian disuntikkan secara intraplantar dengan $0,1 \mathrm{~mL}$ larutan karagenan 1\%. Setelah 30 menit dilakukan pengukuran dengan cara mencelupkan kaki tikus ke dalam pletismometer yang berisi cairan khusus sampai larutan mencapai garis batas atas dan pedal ditahan. Perubahan volume cairan yang terjadi dicatat sebagai volume telapak kaki tikus (Vt). Pengukur dilakukan setiap 30 menit salama 5 jam 30 menit.

Volume radang adalah selisih volume telapak kaki tikus setelah dan sebelum disuntikkan karagenan. Pada waktu pengukuran, volume cairan harus sama setiap kali pengukuran, tanda batas pada tikus harus jelas, kaki tikus harus tercelup sampai batas yang dibuat. 


\section{HASIL DAN PEMBAHASAN}

\section{Perhitungan Rendamen Ekstrak}

Simplisia bunga bugenvil yang digunakan dalam penelitian ini adalah 78 gram dan diperoleh hasil ekstrak etanol bunga bugenvil sebanyak 38,8 gram. Sehingga rendamen yang diperoleh yaitu 44,02\%.

\section{Uji Aktivitas Antiinflamasi Ekstrak Bunga Bugenvil}

Pengujiaan aktivitas antiiflamasi dari ekstrak bunga bugenvil bertujuan untuk mengetahui kemampuan ekstrak untuk menurunkan volume edema pada kaki tikus putih yang telah diinduksi dengan induktor berupa karagenan $1 \%$. Uji aktivitas antiiflamasi ini menggunakan metode induksi karagenan. Obat uji diberikan secara oral. Volume udem kaki diukur dengan alat plestismometer.

Uji aktivitas antiinflamasi dilakukan dengan 4 kelompok yakni 3 kelompok dosis yang dibandingkan dengan kontrol negatif berupa suspensi NaCMC 0,5\%. Berdasarkan uji pendahuluan diperoleh 3 varian dosis yang menunjukkan adanya aktivitas antiinflamasi ekstrak etanol bunga bugenvil yaitu dosis $200 \mathrm{mg} / \mathrm{kg}, 250 \mathrm{mg} / \mathrm{kg}$ dan $300 \mathrm{mg} / \mathrm{kg}$. Parameter aktivitas antiinflamasi ditunjukkan dengan adanya penurunan volume edema pada kaki tikus putih yang diberikan induktor karagenan $1 \%$. Nilai penurunan radang pada kaki tikus putih dilihat dengan membandingkan volume kaki tikus putih setelah induksi dan sebelum diinduksi karagenan. Tikus putih diberikan suspensi uji ekstrak bunga bugenvil (200 mg/kgBB, $250 \mathrm{mg} / \mathrm{kgBB}$ dan $300 \mathrm{mg} / \mathrm{kgBB}$ ), suspensi $\mathrm{NaCMC}$ dan suspensi obat Natrium diklofenak secara oral sebelum diberikan induksi. Hal tersebut bertujuan agar suspensi uji ekstrak etanol bunga bugenvil dapat lebih dahulu menghambat pelepasan mediator inflamasi sehingga inflamasi dapat dihambat. Setelah pemberian secara oral kemudian dilakukan pengukuran volume awal kaki tikus putih sebelum injeksi karagenan yang dinyatakan sebagai $\mathrm{V}_{0}$. Selanjutnya dilakukan pemberian induktor karagenan $1 \%$ sebanyak $0,1 \mathrm{~mL}$ secara intraplantar pada kaki kiri tikus putih dan dilakukan pengukuran volume kaki setiap 30 menit selama 5 jam 30 menit. Pada pengujian ini digunakan 3 replikasi pada setiap kelompok. Hasil pengukuran menunjukkan bahwa pada ekstrak etanol bunga bugenvil dengan dosis $200 \mathrm{mg} / \mathrm{kgBB}$ memberikan efek antiinflamasi yang lebih baik dari varian dosis lainnya, dapat dilihat dari waktu penurunan volume radang yang lebih cepat.

Hasil uji aktivitas antiinflamasi pada kelompok uji ekstrak etanol bunga bugenvil dan kelompok kontrol negatif berupa suspensi NaCMC 0,5\% dapat dilihat pada gambar 1.

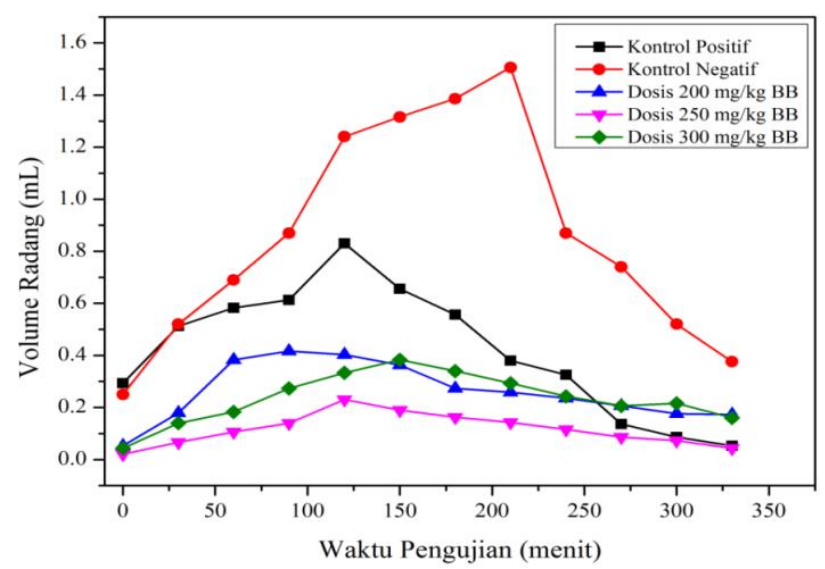

Gambar 1. Grafik aktivitas antiinflamasi ekstrak bunga bugenvil 
Hasil uji aktivitas antiinflamasi menunjukkan bahwa kontrol negatif berupa suspensi NaCMC 0,5\% terjadi peningkatan volume radang dari waktu ke waktu dan puncaknya pada menit ke 210 . Pada menit ke- 240 volume radang kaki tikus putih mulai mengalami penurunan. Hal ini menunjukkan bahwa pada pemberian suspensi NaCMC $0,5 \%$ tidak memberikan efek penurunan volume radang. Penurunan radang untuk kelompok kontrol negatif pada menit ke 240 kemungkinan terjadi karena adanya mekanisme alami tubuh tikus putih dalam menyembuhkan radang.

Beda halnya dengan suspensi uji ekstrak etanol bunga bugenvil dengan beberapa varian dosis yakni $200 \mathrm{mg} / \mathrm{kgBB}, 250 \mathrm{mg} / \mathrm{kgBB}$ dan $300 \mathrm{mg} / \mathrm{kgBB}$. Pada dosis 200 $\mathrm{mg} / \mathrm{kgBB}$ puncak volume radang yakni pada menit ke 90 dan mengalami penurunan pada menit ke 120. Dosis ekstrak $250 \mathrm{mg} / \mathrm{kgBB}$ mengalami penurunan volume radang pada menit ke 150 sedangkan dosis ekstrak $300 \mathrm{mg} / \mathrm{kgBB}$ mengalami penurunan volume radang pada menit ke 180. Dimana semakin ditingkatkan dosis dari ekstrak etanol bunga bugenvil maka kemampuan dalam menurunkan volume radang akan semakin lama. Sehingga bila dilihat dari grafik waktu penurunan volume radang yang lebih cepat adalah pada dosis 200 $\mathrm{mg} / \mathrm{kgBB}$. Namun pada grafik efek aktivitas antiinflamasi yang memperlihatkan penurunan volume radang yang baik adalah pada dosis $250 \mathrm{mg} / \mathrm{kgBB}$ karena penurunannya lebih stabil dibandingkan dengan kedua dosis lainnya dan pada waktu ke 330 menit volume radang hampir mendekati volume semula kaki tikus putih sebelum diinduksi dengan karagenan.

\section{Dosis Efektif Sebagai Antiinflamasi}

Penentuan dosis efektif dari ekstrak etanol bunga bugenvil sebagai antiinflamasi, dimana dosis efektif adalah adalah dosis terbaik yang dapat memberikan efek antiinflamasi dibanding dengan dosis lainnya. Berdasarkan grafik aktivitas antiinflamasi ekstrak etanol bunga bugenvil pada dosis $200 \mathrm{mg} / \mathrm{kgBB}, 250 \mathrm{mg} / \mathrm{kgBB}$ dan $300 \mathrm{mg} / \mathrm{kgBB}$ memberikan efek penurunan radang yang lebih cepat dari pada kontrol negatif. Dosis efektif ditentukan dengan menggunakan uji statistika. Model uji statistika yang digunakan adalah ANOVA 2 (dua) arah untuk mengetahui ada atau tidaknya perbedaan dari pengaruh tiap perlakuan variasi dosis ekstrak etanol bunga bugenvil. Analisis pertama yaitu dengan menganalisis kenormalan data yang berguna untuk mengetahui apakah data tersebut normal dan baik. Berdasarkan uji kenormalan diperoleh nilai signifikansi pada beberapa perlakuan $<\alpha$ $(0,05)$ maka dapat ditarik keputusan bahwa $\mathrm{H}_{0}$ diterima. Hal tersebut menandakan bahwa data volume radang pada kaki tikus putih terdistribusi normal. Selanjutnya dilakukan analisis varian dua arah dengan memasukkan semua variabel namun yang diujikan hanya 3 dosis ekstrak dengan tujuan untuk melihat apakah pada setiap pemberian dosis ekstrak nilai penurunan volume radang pada hewan uji homogen atau tidak. Berdasarkan analisis kehomogenan nilai signifikansi $<0,05$ sehingga $\mathrm{H}_{0}$ ditolak maka dapat disimpulkan bahwa data volume radang hewan uji tiap pemberian dosis ekstrak dan setiap waktu tidak homogen.

Selanjutnya dilakukan uji interaksi untuk mengetahui apakah perbedaan pemberian dosis mempengaruhi terhadap lamanya waktu penurunan volume radang pada kaki tikus putih. Hipotesisnya adalah jika $\mathrm{H}_{0}$ diterima artinya tidak terdapat pengaruh ketiga dosis terhadap lama waktu. Berdasarkan analisis diperoleh bahwa nilai signifikansi < 0,05 maka diputuskan bahwa $\mathrm{H}_{0}$ ditolak dan $\mathrm{H}_{1}$ diterima sehingga dapat disimpulkan bahwa terdapat pengaruh pemberian ketiga dosis terhadap lama waktu penurunan volume radang pada kaki tikus putih. Oleh karena itu perlu dilakukan uji lanjutan untuk mengetahui letak perbedaannya. 
Uji lanjutan yang dilakukan adalah uji Tukey dan dari analisis menunjukkan bahwa ada perbedaan yang signifikan antara dosis $200 \mathrm{mg} / \mathrm{kgBB}$ dengan dosis $250 \mathrm{mg}$ dan kontrol negatif. Ada perbedaan antara dosis $250 \mathrm{mg} / \mathrm{kgBB}$ dengan dosis $200 \mathrm{mg} / \mathrm{kgBB}$ dan kontrol negatif. Pada dosis $300 \mathrm{mg} / \mathrm{kgBB}$ terdapat perbedaan dengan kontrol negatif. Dan terdapat perbedaan antara kontrol negatif terhadap semua pemberian dosis ekstrak bunga bugenvil. Selanjutnya dapat dilihat nilai Mean yang menyatakan bahwa pada dosis 200 $\mathrm{mg} / \mathrm{kgBB}$ dan $300 \mathrm{mg} / \mathrm{kgBB}$ tidak ada perbedaan yang nyata sehingga dapat dinyatakan bahwa ke dua dosis ekstrak tersebut memiliki efek yang hampir sama dalam menurunkan volume radang pada kaki tikus putih. Sehingga dapat disimpulkan bahwa dosis efektif ekstrak etanol bunga bugenvil sebagai antiinflamasi adalah pada dosis $250 \mathrm{mg} / \mathrm{kgBB}$. Selain itu juga dapat dilihat dari waktu penurunan volume radang pada dosis $250 \mathrm{mg} / \mathrm{kg}$ yang stabil bila dibandingkan dengan dosis $200 \mathrm{mg} / \mathrm{kgBB}$ dan $300 \mathrm{mg} / \mathrm{kgBB}$ dan mampu menurunkan volume kaki hampir kembali ke volume awal kaki tikus putih.

\section{Uji Potensi Ekstrak Bunga Bugenvil}

Ekstrak etanol bunga bugenvil memiliki aktivitas sebagai antiinflamasi yang telah dinyatakan pada pengujian sebelumnya. Dimana pada dosis $200 \mathrm{mg} / \mathrm{kgBB}, 250 \mathrm{mg} / \mathrm{kgBB}$ dan $300 \mathrm{mg} / \mathrm{kg}$ menunjukkan bahwa waktu penurunan volume radang ketiga varian dosis lebih cepat dibandingkan dengan kontrol negatif. Berdasarkan uji aktivitas antiinflamasi maka dilakukan pula uji lanjutan untuk mengetahui potensi dari ekstrak terbaik dalam menurunkan volume radang dibandingkan dengan kontrol positif berupa Natrium diklofenak $50 \mathrm{mg}$. Uji potensi dilakukan dengan membandingkan dosis efektif ekstrak etanol bunga bugenvil terhadap kontrol positif. Berdasarkan analisis sebelumnya dijelaskan bahwa dosis efektif terdapat pada dosis $250 \mathrm{mg} / \mathrm{kgBB}$. Perbedaan aktivitas antiinflamasi dari ekstrak $250 \mathrm{mg} / \mathrm{kgBB}$ dengan kontrol positif dapat dilihat secara visual pada grafik 2 .

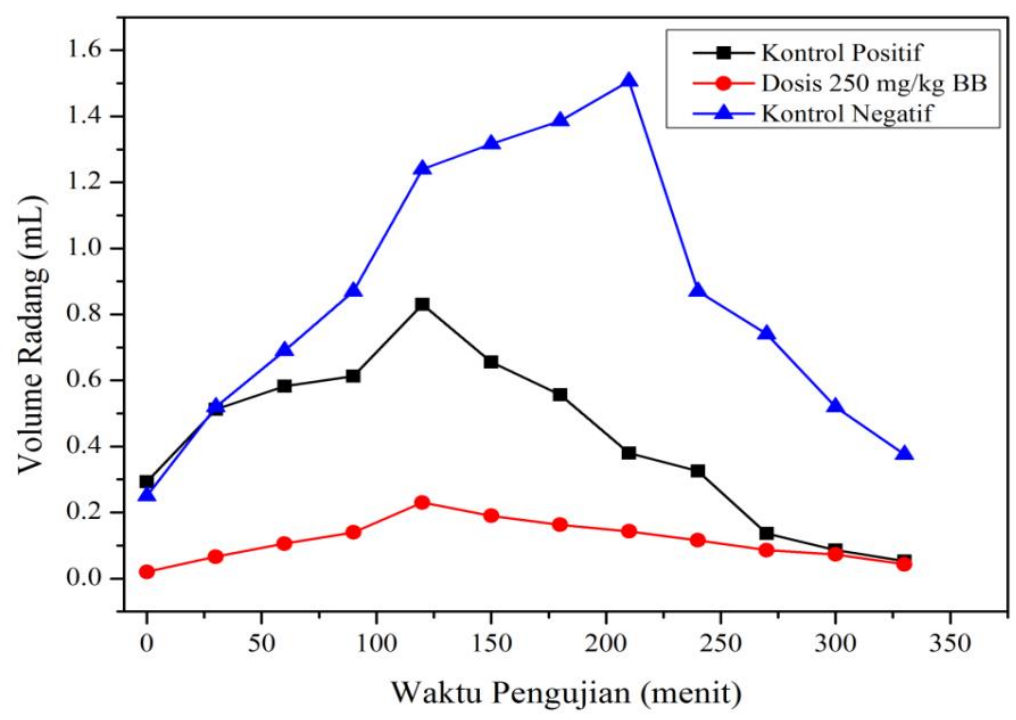

Gambar 2. Grafik Perbandingan Potensi Antiinflamasi Ekstrak Bunga Bugenvil

Dari gambar 2 dapat dilihat bahwa dosis ekstrak $250 \mathrm{mg} / \mathrm{kgBB}$ memberikan efek penurunan volume radang pada waktu ke-150 menit dan sama halnya dengan kontrol positif yang memberikan efek pada waktu ke-150 menit. Berdasarkan analisis uji potensi diperoleh hasil bahwa nilai signifikansi $<0,05$ maka dapat dinyatakan bahwa terdapat 
perbedaan yang nyata antara pemberian dosis $250 \mathrm{mg} / \mathrm{kgBB}$ dengan kontrol positif berupa

Natrium diklofenak $50 \mathrm{mg}$.

\section{KESIMPULAN DAN SARAN} berikut :

Berdasarkan hasil penelitian yang dilakukan dapat diambil kesimpulan sebagai

1. Rendamen ekstrak bunga bugenvil (Bougainvillea spectabilis) yang didapatkan dari ekstraksi dengan menggunakan pelarut etanol $70 \%$ adalah sebesar 44,02\% dari simplisia kering 87 gram dan ekstrak 38,8 gram.

2. Ekstrak bunga bugenvil (Bougainvillea spectabilis) memiliki aktivitas sebagai antiinflamasi pada dosis $200 \mathrm{mg} / \mathrm{kgBB}, 250 \mathrm{mg} / \mathrm{kgBB}$ dan $300 \mathrm{mg} / \mathrm{kgBB}$.

3. Dosis efektif ekstrak bunga bugenvil (Bougainvillea spectabilis) terhadap penurunan volume radang tikus putih adalah pada dosis $250 \mathrm{mg} / \mathrm{kgBB}$.

4. Uji potensi menyatakan bahwa terdapat perbedaan antara dosis efektif (250mg/kgBB) ekstrak etanol bunga bugenvil (Bougainvillea spectabilis) terhadap natrium diklfenak $50 \mathrm{mg}$ (kontrol positif).

\section{DAFTAR PUSTAKA}

1. Enciso, Oswaldo. 2012. Antibacterial Activity of Bougainvillea glabra, Eucalyptus glabulus, Gnaphalium attenuatum and Propolis Collected in Mexico. Pharmacology and Pharmacy. Vol 3. 433-438.

2. Joshny. 2012. Phytochemical and In-Vitro Anthelmintic Activity of Hydro Alcoholic Extract of Bougaivillea glabra. International Journal of Pharmacy and Pharmaceutical Sciences. Vol 4: 115-117

3. Kobayashi. 2007. Bougainvillea, Available From The Department of Tropical Plant and Soil Sciences. The College of Tropical Agriculture and Human Resources Ornamentals and Flowers. 38: 1-6.

4. Rashid, Farzana. 2013. Phytochemical Analysis and Inhibitory Activity of Ornamental Plant (Bougainvillea spectabilis). Asian Journal of Plant Science and Research. 3(2): 1-5.

5. Sahu, Neha dan Jyoti. 2012. Comparative Phytochemical Analysis of Bougainvillea glabra Choisy and Calforina Gold. International Journal of Pharma and Bio Sciences. 3 (3). 247-250. 